\title{
Hyporheic Zone Hydrochemistry of the Mine-Polluted River
}

\author{
D. Ciszewski, P. Bijata \\ AGH-University of Sciences and Technology, Kraków, Poland \\ Email: ciszewski@geol.agh.edu.pl
}

Received November 2015

\begin{abstract}
Intensity of stream waters mixing with groundwaters and lateral extent of these processes in the hyporheic zone were investigated in a near-bank sandbar and an adjacent floodplain through the comparison of groundwaters and stream water chemistry of the Biała Przemsza River in southern Poland. The stream waters were polluted by the discharge of mine waters from "Bolesław" lead and zinc mine. The investigated waters were several times more mineralized than the natural spring waters of the river valley. The concentration of: potassium, sodium, and the $\mathrm{pH}$, as well as cadmium, lead, and zinc decreased in the hyporheic zone towards the stream bank, whereas conductance, calcium, magnesium, sulphates, as well as silica contents were the highest on the floodplain, diminishing towards the stream. The changes observed in the chemical composition of groundwaters were apparent in mixing stream waters below the depth of $2 \mathrm{~m}$ with shallow groundwaters draining the valley slope. Hyporheic mixing also takes place in the 10-meter-wide, marginal zone of the sandbar, whereas in the 5-meter-wide stream-side zone of the sandbar groundwaters represent weakly transformed stream water.
\end{abstract}

\section{Keywords}

Hyporheic Zone, Groundwaters, Pollution, Water Chemistry, Metal Mining

\section{Introduction}

The hyporheic zone is an area beneath and adjacent to the stream where stream waters mix with groundwaters. This zone contains from several per cent up to $100 \%$ of river waters which penetrate alluvia over distances from centimetres to kilometres from the channel and several meters below the channel bottom (Woessner, 2000) [1]. Intensive investigations of the hyporheic zone during two most recent decades revealed their important ecological role. It was found that a channel bottom constitutes a shelter for hyporheic organisms which are unique for this specific ecotone. This ecotone can act as a physical, chemical and biological filter capable of transforming nutrients and pollutants (Bourg \& Bertin, 1993) [2]. Microbial biofilms, in particular, mediate the transformation of water chemistry and affect the nitrogen cycling within the river system. Typically, along the hyporheic flow path well-oxygenated stream waters infiltrating through the bottom lose oxygen during nitrification, followed by denitrification in anoxic conditions, before unaerated waters reenter the stream (Hancock, Boulton \& Humphreys, 2005) [3]. High oxygen, temperature and flow velocity gradients in the hyporheic zone, together with 
the microbial activity, favour the transformation of contaminants transported by the streams affected by mining. Studies of gravel alluvia also recognized the precipitation of manganese and iron oxides on coarse grains as an important mechanism controlling the removal of heavy metals from river waters (Fuller \& Bargar, 2014) [4].

Whereas the hyporheic zone is extensively studied on gravel-bed rivers and gravel bars (considered as part of this zone), the processes of contaminant transformation are much less recognized in the sandy alluvia. Sandy river beds are more mobile and this mobility was found to affect the storage and transformation of solutes and fine particles (Harvey et al., 2012) [5]. The aim of the study was to recognize the relative importance of the hyporheic flow in the sand bar of the Biała Przemsza River channel, cut in the fine grained alluvia, which are typical for the Pleistocene sediments in Central Europe. The river channel is polluted by the discharge of mine waters from "Bolesław" lead and zinc mine in southern Poland. The chemistry of the river water is markedly altered due to the discharged waters, thus their comparison to groundwater chemistry was used to reveal the lateral extent of the hyporheic zone.

\section{Method}

The Biała Przemsza River is the left-bank tributary of the Vistula River, which is the longest and largest river of Poland. The Biała Przemsza, with the length of over 60 kilometres, drains the upland area of the most industrialized region of Poland called Upper Silesia. The river valley is several hundred meters wide when it crosses cuesta sections, built of carboniferous rocks, and is several kilometres wide in inter-cuesta basins filled with fluvioglacial sandy deposits, with a thickness of as much as $25 \mathrm{~m}$. In the studied middle river reach the valley gradient decreases and the channel reaches the width of up to $50 \mathrm{~m}$ because the sandy sediments accumulate, forming mid- and side channel bars (Figure 1). The tendency for the accretion of bed material has been observed here since the middle of the $19^{\text {th }}$ century when weirs protecting the railway bridge and later the water supply plant had been constructed about $2 \mathrm{~km}$ downstream. These constructions, together with the valley narrowing by the high Pleistocene terrace in this river section, induced the lateral channel stabilization over the course of the $20^{\text {th }}$ century. This stabilization favoured the development of the turf grass cover over most of the sand bars in this river reach as their surface became closer to the average level of the water table. The average discharge of the Biala Przemsza River in this reach equalled $4 \mathrm{~m}^{3} / \mathrm{s}$ with a half of it originating from one of the largest lead and zinc mines in Europe - the "Bolesław" Mine and Metallurgical Plant (ZGH). The plant discharges mine water with higher-than-natural mineralization, the content of zinc, lead, cadmium, and turbidity, which has decreased since the beginning of the mine operation (Ciszewski, 1998) [6].

Seven sediment cores were collected from the 20-metre-long transect across the side channel bar and the floodplain of the Biała Przemsza River at Maczki (Figure 1). Four sediment cores were drilled to the depth of 4 meters and three profiles - up to 1 meter deep. In the core sites, 4- and 1-meter long piezometers were installed. Sediment cores were split into sections about $30 \mathrm{~cm}$ long and transported to a laboratory for analyses. Samples of groundwaters and stream waters were collected 10 times over the period of one year. The values of the $\mathrm{pH}$ and conductance were established using a Thermo Scientific device. The samples were filtered before the analy-

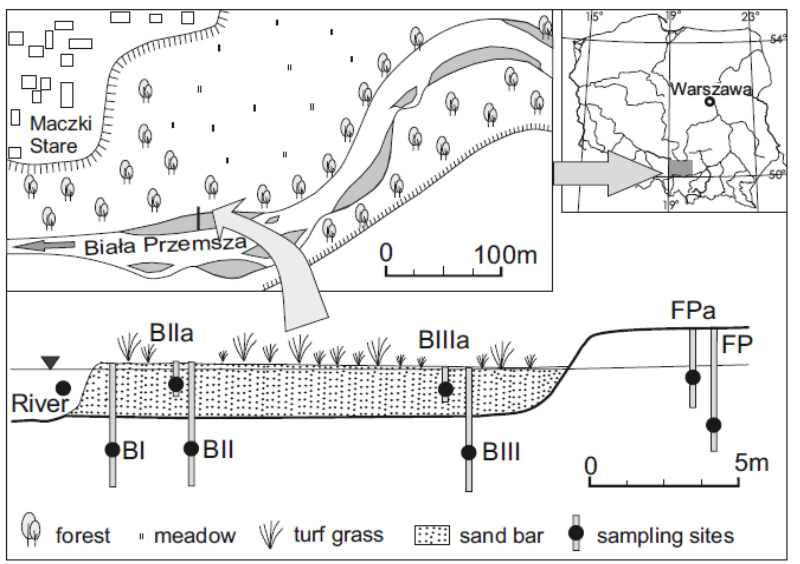

Figure 1. Location of sampling sites of river water and groundwater in the channel bar (B) and in the floodplain (FP) (black dots). 
sis through $0.45 \mu \mathrm{m}$ filters and concentrations of $\mathrm{Cl}^{-}, \mathrm{NO}_{3}^{-}, \mathrm{SO}_{4}^{2-}, \mathrm{PO}_{4}^{3-}, \mathrm{CO}_{3}^{2-}$ and macroions (Ca, $\mathrm{Mg}, \mathrm{Na}$, $\mathrm{K}$ ) were determined within $48 \mathrm{~h}$ using Ion Chromatography (DIONEX 1000). Standard reference materials (Canadian waters Hamilton-20) were employed to determine the accuracy of anion analyses. For analyses of $\mathrm{Zn}, \mathrm{Cd}$, $\mathrm{Pb}, \mathrm{Fe}, \mathrm{Ba}$ and $\mathrm{Si}$, the waters were filtered on site through a syringe filter $0.45 \mu \mathrm{m}$, acidified to a $\mathrm{pH}$ below 2 with ultrapure $\mathrm{HNO}_{3}$ and measured with an inductively coupled plasma-mass spectrometer (Perkin Elmer ELAN 6100) in the certified Hydrogeochemical Laboratory according to the standard certified analytical quality control procedure (PN-EN ISO 17294-1:2007). In the collected sediments, losses on ignition at $550^{\circ} \mathrm{C}$ and content of 0.2 $\mathrm{mm}$ fraction were analyzed after drying at $105^{\circ} \mathrm{C}$.

\section{Results}

Groundwater levels in the sandbar varied within less than $10 \mathrm{~cm}$ over the study period and were never recorded below $20 \mathrm{~cm}$ of the bar surface. The groundwater depths on the floodplain varied between 68 and $78 \mathrm{~cm}$ within the year. No head gradient was observed within the channel bar. Generally, the average conductance of stream waters was high and equalled $885 \mu \mathrm{S}$ (Table 1). Very similar values were in groundwaters within 5 meters from the bar edge and they increased markedly at the river bank. These values were higher at the surface than at greater depths and on the floodplain.

The opposite distribution pattern was observed for the $\mathrm{pH}$. Whereas stream waters were alkaline, with the $\mathrm{pH}$ of 8, groundwaters became more acidified further away from the stream, reaching 6.5 on the floodplain (Figure 2). In the same sampling site (II, III or FP) more acidified waters occurred closer to the surface than at the depth

Table 1. River and ground waters characteristics from the sampling sites in the channel bar (B) and in the floodplain (FP) of the Biała Przemsza river at Maczki (Median values) $\left[\mathrm{mg} / \mathrm{dm}^{3}\right]$; n.d.: not detected.

\begin{tabular}{|c|c|c|c|c|c|c|c|c|c|}
\hline $\begin{array}{l}\text { Water chemistry } \\
\text { characteristics }\end{array}$ & River & $\begin{array}{c}\text { B I } \\
\text { depth } 3 \mathrm{~m}\end{array}$ & $\begin{array}{c}\text { B II } \\
\text { depth } 3 \mathrm{~m}\end{array}$ & $\begin{array}{c}\text { B IIA } \\
\text { depth } 0.6 \mathrm{~m}\end{array}$ & $\begin{array}{c}\text { B III } \\
\text { depth } 3 \mathrm{~m}\end{array}$ & $\begin{array}{c}\text { B IIIA } \\
\text { depth } 0.6 \mathrm{~m}\end{array}$ & $\begin{array}{c}\text { FP I } \\
\text { depth } 3 \mathrm{~m}\end{array}$ & $\begin{array}{c}\text { FP IA } \\
\text { depth } 1 \mathrm{~m}\end{array}$ & $\begin{array}{l}\text { Natura } \\
\text { spring }\end{array}$ \\
\hline Conductivity $(\mu \mathrm{S})$ & 885 & 880 & 875 & 904 & 831 & 979 & 961 & 915 & 228 \\
\hline $\mathrm{pH}$ & 8.1 & 7.5 & 7.5 & 6.8 & 7.3 & 6.9 & 7.0 & 6.5 & 6.5 \\
\hline $\mathrm{Ca}$ & 118 & 120 & 115 & 129 & 118 & 141 & 135 & 134 & 30 \\
\hline $\mathrm{Mg}$ & 33 & 32 & 32 & 30 & 33 & 35 & 37 & 36 & 7 \\
\hline $\mathrm{Na}$ & 22 & 26.3 & 23 & 21 & 17 & 11 & 21 & 9 & 3 \\
\hline K & 5.6 & 6.8 & 5.1 & 4.0 & 4.8 & 4.5 & 3.0 & 0.8 & 2 \\
\hline $\mathrm{NH}_{4}$ & 0.72 & 0.02 & 0.47 & 0.16 & 0.72 & 0.51 & 0.19 & 0.44 & 0.01 \\
\hline $\mathrm{HCO}_{3}$ & 278 & 268 & 273 & 341 & 273 & 390 & 311 & 297 & 76 \\
\hline $\mathrm{SO}_{4}$ & 198 & 199 & 210 & 181 & 179 & 191 & 248 & 211 & 35 \\
\hline $\mathrm{Cl}$ & 35 & 31 & 33 & 28 & 28 & 29 & 33 & 31 & 8 \\
\hline $\mathrm{NO}_{3}$ & 8.4 & 1.53 & nd. & nd. & nd. & nd. & nd. & 5.2 & 2.4 \\
\hline $\mathrm{NO}_{2}$ & 0.22 & 0.21 & nd. & nd. & nd. & nd. & nd. & 0.67 & nd. \\
\hline $\mathrm{PO}_{4}$ & 0.39 & 0.01 & nd. & nd. & nd. & nd. & nd. & nd. & nd. \\
\hline $\mathrm{F}$ & 0.74 & 0.269 & 0.37 & 0.35 & 0.46 & 0.270 & 0.16 & 0.308 & 0.1 \\
\hline $\mathrm{Ba}\left(\mu \mathrm{g} / \mathrm{dm}^{3}\right)$ & 91 & 111 & 211 & 129 & 290 & 127 & 259 & 148 & 80 \\
\hline $\mathrm{Cd}\left(\mu \mathrm{g} / \mathrm{dm}^{3}\right)$ & 3.5 & $<0.1$ & $<0.1$ & $<0.1$ & $<0.1$ & $<0.1$ & $<0.1$ & 3.3 & nd. \\
\hline $\mathrm{Pb}\left(\mu \mathrm{g} / \mathrm{dm}^{3}\right)$ & 36 & 5.4 & 2.1 & 5.0 & 2.8 & 6.2 & 11.5 & 32 & 3.1 \\
\hline $\mathrm{Zn}\left(\mu \mathrm{g} / \mathrm{dm}^{3}\right)$ & 878 & 284 & 14 & 681 & 11 & 21 & 11 & 950 & 30 \\
\hline $\mathrm{Fe}\left(\mu \mathrm{g} / \mathrm{dm}^{3}\right)$ & 148 & 59 & 798 & 6795 & 3042 & 12,006 & 4804 & 940 & 300 \\
\hline $\mathrm{Si}\left(\mu \mathrm{g} / \mathrm{dm}^{3}\right)$ & 8792 & 7982 & 7890 & 9470 & 8437 & 10,471 & 8357 & 16,231 & 12,650 \\
\hline
\end{tabular}



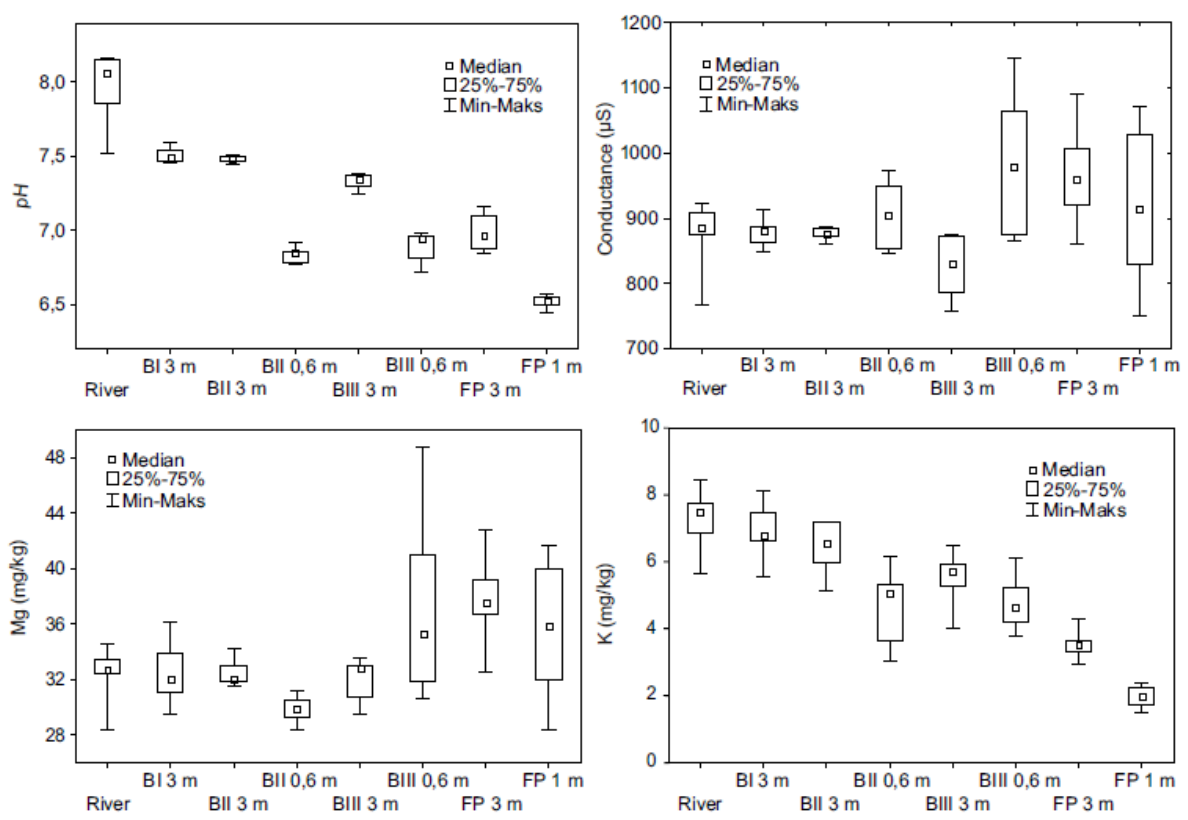

Figure 2. Variability of the $\mathrm{pH}$, conductance and $\mathrm{Mg}$ and $\mathrm{K}$ concentrations in waters sampled from the river and from different depths of the channel bar (B) and of the floodplain (FP).

of $3 \mathrm{~m}$. Very similar distribution pattern was observed for potassium as the maximum concentrations of this element occurred in the stream waters and there were markedly lower values in the floodplain; the decrease of this element content from the stream was progressive (Figure 2). Higher concentrations in stream waters than in floodplain groundwaters were observed also for sodium and its changes were closely associated with those of potassium (Table 1). Particularly low sodium values were recorded in shallow floodplain waters, whereas at the depth of $3 \mathrm{~m}$ the content of both elements was much higher or even similar to that in the river.

In contrast with sodium and potassium, magnesium exhibited the distribution pattern similar to that of the conductance. Differences between waters of the floodplain and those of the channel bar were not very high, but statistically significant. Intermediate values characterized shallow waters from the marginal zone of the channel but they varied markedly over the investigated period (BIIIA, Figure 2). Variability of calcium was also similar to that of magnesium; calcium content in the surface waters was generally lower than in the sandbar close to the stream (BI, BII) and increased at the channel margin and on the floodplain.

River waters were markedly polluted with sulphates to the level of about $200 \mathrm{mg} / \mathrm{l}$, but their content did not differ significantly from the values for the channel bar. Only values at the deep horizon of the floodplain were markedly higher than the rest of the investigated points. Hydrocarbonates with the content of about $280-300$ $\mathrm{mg} / \mathrm{l}$ were more uniformly distributed in the investigated transect with significantly (statistically) higher values only in shallow waters of the sandbar. Their concentration in floodplain waters was only slightly higher than that in the river. Concentration of chlorides was also weakly differentiated with the highest values, on average, in the stream. Detectable values of nitrates, nitrites and phosphates occurred solely in the stream, in close proximity to the stream (BI) and at the floodplain surface (FPI). Concentrations of all these compounds were at least several times higher than in the natural spring water draining the Pleistocene terrace about $3 \mathrm{~km}$ upstream the sampling site (Table 1).

The sediments of the sandbar were composed almost exclusively of uniform, medium grained sands. The content of the fine fraction of sand and silt did not exceed several per cent in almost all strata of sediment cores. The highest content of the fine fraction was found at the surface of the sandbar. The surface $0.3 \mathrm{~m}$ strata contained also up to $10 \%$ of organic matter. However, some lenses of more organic and finer grained deposits were also observed at lower depths of the profiles.

\section{Discussion}

There are several methods of investigation of groundwater and surface waters interactions in the hyporheic zone. 
In addition to the direct flow measurements, pumping tests, temperature measurements or solute tracing, contaminants may be used as markers for stream water or groundwater which mix beneath the stream (Kalbus, Reinstorf \& Schirmer, 2006) [7]. Hydrochemical methods are particularly effective where chemical properties of stream water and groundwater differ markedly (Woessner, 2000; Hoehn \& Scholtis, 2011) [1] [8]. In the presented studies this difference was used in order to identify the relative intensity of mixing of the two types of water. Two different distribution patterns of chemical compounds were identified. In one of them the concentrations decreased from the highest in the stream towards the lowest in the floodplain. It is represented by potassium, sodium and the $\mathrm{pH}$, as well as by cadmium, lead, and zinc. The opposite distribution, with overall higher values in the floodplain and lower in the stream and in the sandbar, is represented by conductance, calcium, magnesium, and sulphates, as well as silica. These differences are less visible for chlorides, hydrocarbonates, barium, and iron and seem to represent an intermediate distribution pattern. The observed distribution patterns indicate that shallow groundwaters in the floodplain differ markedly from the rest of the waters because they drain a large area of the valley slope and have a prolonged contact with the subsurface. This is particularly visible in the highest content of silica. The groundwaters at lower levels were for some compounds more closely related to groundwaters which drain the floodplain and some concentrations were more similar to that in the sandbar at the channel margin under the influence of water from the stream. High variability also characterizes concentrations of many compounds in the subsurface waters at the channel margin (BIIIA). The influence of water draining the floodplain is higher during rainfall or snow-melting periods and only the channel margins are the zone of most intensive mixing of ground and stream waters. The proportion of stream waters at the depth of $3 \mathrm{~m}$ on the floodplain seems to be quite high, considering the chlorides content is as high as in the stream. Nevertheless, it is clearly visible that the proportion of stream waters is the highest closer to the stream. In particular, the concentrations of most of the compounds in BI and BII sites i.e. in the marginal zone of the sandbar about 5 metres wide are almost the same as in the stream. It seems that in this zone $100 \%$ of stream water flow is parallel or the intensive exchange with the stream and lateral groundwater inflow from the floodplain occurs at the channel margin, where stream waters mix with groundwaters in variable proportions. This zone is characterized by the highest average conductance. The data enabled the identification of the hyporheic zone extending over the channel bar and outside the river channel below the depth of $2 \mathrm{~m}$.

Investigations of hyporheic exchange processes in partially submerged bed structures use observations of stream stage, head data in piezometers, artificial tracer additions or variations in natural electrical conductivity and were attempted mainly in gravel bed rivers (Trauth et al., 2015) [9]. The electrical conductivity and the other characteristics of water in the sandbar were used to show high complexity of the morphological factors controlling the exchange in the sandy alluvia. These investigations indicated that sand bars, particularly at channel margins, not actively reworked in the channel, may not have a uniform structure. The sediments accreted during numerous flood episodes contain some stratification which modify the flow velocity in the hyporheic zone. The bars formed at the channel margin shift out of the bank both the flow and the zone of the flow parallel to the channel, sometimes called the parafluvial zone (Boulton et al. 1998) [10]. As a result, hyporheic mixing processes occur as well within the channel in a zone proportional to the width of the channel bar and their grain size variability.

The mixing processes seem to be connected to the conservative behaviour of chemical compounds. However, some substances are biologically transformed in the hyporheic zone. Nitrates and nitrites, abundant in the stream water, had to have already disappeared in the BI point, localized a few decimetres from the bar edge (Table 1). The same substances are also present only in the surface waters of the floodplain. This suggests that microbial reduction of nitrogen load is intensive and takes place within the decimetres of the flow in the hyporheic zone. The widespread absence of oxygen in the sandbar or its very low content $(<0.5 \mathrm{mg} / \mathrm{l})$ only in the BI site at the bar edge, demonstrates its rapid drop in the fully oxygenated $(10 \mathrm{mg} / \mathrm{l})$ river waters infiltrating the sand bar. Some of the other chemical compounds can also be transformed within the channel bar. The loss of phosphates from the stream waters is suggested by its rapid decrease already at the bar margin. Moreover, processes of dissolution of iron hydroxides are responsible for very high iron content in the subsurface waters on the sandbar. These processes are characteristic of the reducible dissolution of iron compounds in the presence of organic matter and also occur in the swampy areas of the Biała Przemsza River valley.

\section{Conclusion}

Stream waters polluted by the discharge from "Bolesław" lead and zinc mine are more abundant in most of the 
chemical compounds investigated than in the natural spring waters of the Biała Przemsza River valley. The concentrations of potassium, sodium, and the $\mathrm{pH}$, as well as cadmium, lead, and zinc decreased in the hyporheic zone towards the stream banks, whereas conductance, calcium, magnesium, and sulphates, as well as silica contents were higher on the floodplain and decreased towards the stream. The observed changes in the chemical composition of the groundwater exhibit the inflow of shallow groundwater from the catchment mixing with stream water below the depth of $2 \mathrm{~m}$. Hyporheic mixing extends along the bank and within the approximately 10-metre-wide marginal zone of the sandbar, whereas in the 5-metre-wide marginal zone of the sandbar, groundwaters represent weakly transformed stream waters flowing along the stream.

\section{Acknowledgements}

The authors gratefully acknowledge the National Science Center of Poland for funding the project No. 2012/05/B/ST10/00235.

\section{References}

[1] Woessner, W.W. (2000) Streams and Fluvial Plain Ground Water Interactions: Rescaling Hydrogeologic Thought. Ground Water, 38, 423-429. http://dx.doi.org/10.1111/j.1745-6584.2000.tb00228.x

[2] Bourg, A.C.M. and Bertine, C. (1993) Biogeochemical Processes during the Infiltration of River Water into an Alluvial Aquifer. Environmental Science and Technology, 27, 661-666. http://dx.doi.org/10.1021/es00041a009

[3] Hancock, P.J., Boulton, A.J. and Humphreys, W.F. (2005) Aquifers and Hyporheic Zones: Towards an Ecological Understanding of Groundwater. Hydrogeological Journal, 13, 98-111. http://dx.doi.org/10.1007/s10040-004-0421-6

[4] Fuller, Ch.C. and Bargar, J.C. (2014) Processes of Zinc Attenuation by Biogenic Manganese Oxides Forming in Hyporheic Zone of Pinal Creek, Arizona. Environmental Sciences and Technology, 48, 2165-2172. http://dx.doi.org/10.1021/es402576f

[5] Harvey, J.W., Drummond, J.D., Martin, R.L., McPhillips, L.E., Packman, A.I., Jerolmack, D.J., Stonedahl, S.H., Aubenau, A.F., Sawyer, A.H., Larsen, L.G. and Tobias, C.R. (2012) Hydrogeomorphology of the Hyporheic Zone: Stream Solute and Fine Particle Interactions with Dynamic Streambed. Journal of Geophysical Research, 117, 1-20. http://dx.doi.org/10.1029/2012JG002043

[6] Ciszewski, D. (1998) Channel Processes as a Factor Controlling Accumulation of Heavy Metals in River Bottom Sediments: Consequences for Pollution Monitoring (Upper Silesia, Poland). Environmental Geology, 36, 45-54. http://dx.doi.org/10.1007/s002540050319

[7] Kalbus, E., Reinstorf, F. and Schirmer, M. (2006) Measuring Methods for Groundwater-Surface Water Interactions: A Review. Hydrology and Earth System Science, 10, 873-887. http://dx.doi.org/10.5194/hess-10-873-2006

[8] Hoehn, E. and Scholtis, A. (2011) Exchange between a River and Groundwater, Assessed with Hydrochemical Data. Hydrology and Earth System Science, 7, 9023-9042. http://dx.doi.org/10.5194/hessd-7-9023-2010

[9] Trauth, N., Schmidt, Ch., Vieweg, M., Oswald, S.E. and Fleckenstein, J.H. (2015) Hydraulic Controls of In-Stream Gravel Bar Hyporheic Exchange and Reactions. Water Resources Research, 51, 2243-2263. http://dx.doi.org/10.1002/2014WR015857

[10] Boulton, A.J., Findlay, S., Marmonier, P., Stanley, E.H. and Valet, H.M. (1998) The Functional Significance of the Hyporheic Zone in Streams and Rivers. Annual Review of Ecological Systems, 29, 59-81. http://dx.doi.org/10.1146/annurev.ecolsys.29.1.59 